\title{
Health Care Provided by Hospital Staff and its Relation with Quality of Administrative System of Hospital
}

\author{
Amany A. El Nahas ${ }^{1}$, Manal M. Bakr², Nabila, M. Shrief ${ }^{3}$ \\ Nurse specialist, Technical Nursing Institute, Kafr El-Sheikh, Assistant professor of Nursing \\ Administration, Lecturer of Nursing Administration, Faculty of Nursing, Menoufia University, Egypt
}

\begin{abstract}
Quality of health care is the highest priority for professionals in hospital management. The decisions made and actions taken by hospital managers have a direct effect on patient care within organization throughout processes common to all management like planning, organizing, staffing, directing and controlling. The purpose of the study was to examine the health care provided by hospital staff and its relation with of quality of administrative system. Design: A descriptive correlational research design. Setting: This study was conducted at inpatient and critical care units at Menoufia University Hospitals. Methods: Simple random sample for each category of study participants was selected. Staff nurses (134), physicians (32), administrative employees (199) and patients (75). Two instruments were used. The first instrument was staff questionnaire sheet to assess hospital staff perception regarding to quality of administrative system at Menoufia University hospital. The second instrument was patients structured interview to investigate the patients' perception toward quality of health care provided by hospital staff in Menoufia University hospital. Results: The findings of the study indicated that $50.2 \%$ of administrative employees perceived that the quality of administrative systems to be moderate. Nursing staff showed a nearby perception $(52.2 \%)$. There was a statistical positive correlation between the quality of administrative systems from the perception of nurses, physicians and health care employees and quality of health care provided to patients. Conclusion: Low percent of patients perceived that the health services provided by hospital staff was low, more than two thirds of patients perceived that the health services provided by hospital staff was moderate and less than one-fifth of patients perceived that the health services provided by MUH was high. Recommendations: in-service educational programs based on the management educational needs for novice nursing and medical staff must be developed to improve the quality of administrative tasks. Further researches in Egypt are needed to assess barriers that affect quality of administrative tasks among nurse managers.
\end{abstract}

Keywords: Health Care, Quality, Administrative System.

\section{Introduction}

The administrative system of the hospital is defined by the Joint Commission on Accreditation of Hospitals as includes a governing board that represents the community, an executive committee that is responsible for patient care activities and is supported by standing committees, and a hospital administrative unit consisting of a chief administrator and numerous assistants (Dibiaggio and White, 2015).

Administrative tasks done at the highest level of management hierarchy of the organization. On the other hand, management creates and maintains internal environment in the organization for individuals and groups to perform effectively. Good administrative tasks include supportive visionary management and proper planning which improve the healthcare quality in the organizations (Barr, 2012).

Health Care Organizations are the organizations that provide offerings to clinical authorities like nurses, doctors, pharmacists, etc. Their fundamental purpose is to provide good services at the lowest cost and better amount to a large number of patients. They are centers that provides health services such as diagnosis of diseases, surgical operations, treatment, and recovery of patients (Kelly, 2012).

Health organizations must be concerned with the scope and quality of the services provided to patients. Therefore, the manager has to think about the skills that an effective manager must utilize (Siddiqui, 2016). 


\section{Health Care Provided by Hospital Staff and its Relation with Quality of Administrative System of Hospital}

Health care service depends on quality of administrative system, services and service provider interactions. Good healthcare quality means providing patients with appropriate services in a technically competent manner, with good communication, shared decision-making and cultural sensitivity (Mosadeghrad, 2014).

Due to complexities of health care services and systems, the investigating and interpreting the use of costs, quality, accessibility, financing, and outcomes of health care services is key to inform the health care providers, and consumers about the health related issues (Hughes and Steinwachs, 2008).

Health care practitioners provide health care for patients depending on the use of scientific methods and evidence based practice to develop and implement high quality patient care and evaluate the progression of health status each patient (Kelly, 2012).

Quality is the ability of a product and service to satisfy stated or implied needs. It is the degree to meet customer or patient expectation. Health care quality is the degree to which services for individuals and population increase the likelihood of desired health outcomes. Nurses comprise the largest group of health care providers and responsible for the quality of care they provide to patients. Improving quality through improving structures and processes leads to a reduction of waste, rework, and delays, lower costs, higher market share, and create a positive hospital image (Marquis, and Huston, 2011).

Structure, represents the first component of quality care model. Structure means the conditions under which the care is provided. Such conditions include human resources (professionals) and material resources (facilities), and organizational characteristics at different levels (Salah, 2016).

Process, represents the second component of quality care model. It refers to what we do for patients and their families. The process can be classified into planning, organizing, directing, staffing and controlling. The process assess whether a patient receive good care or not (Petri and Kazemi, 2015).

Outcome completes the quality framework. Outcomes reflect the presence of structure and process elements of quality. Outcome elements of quality are the end results of quality care. If a quality hospital (structure) and quality standards (process) are in place, patients should experience good health (Wolper, 2011).

Many studies found that employees with better planning and decision-making skills more likely to be promoted into management jobs, and be successful as managers which lead to create a positive environment that promotes good health, improved patient outcomes and achieve higher quality patient care (Williams, 2013).

\section{Purpose of the study}

The purpose was to examine the health care provided by hospital staff and its relation with quality of administrative system.

\section{Research Question}

1- What are the quality levels of administrative system at Menoufia university hospital structure, process and outcome?

2- What are the levels of health care provided to the patients?

3- What is the relationship between quality of administrative system and level of care provided to the patients in Menoufia university hospitals?

\section{Methods}

- Research design: A descriptive correlational research design was utilized in the current study.

- Research setting: This study was conducted at inpatient and critical care units at Menoufia University Hospitals.

- Sampling: Sample size has been calculated using the following equation: $n=$ $[\mathrm{DEFF} * \mathrm{~Np} \quad(1-\mathrm{p})] / \quad[(\mathrm{d} 2 / \mathrm{Z} 21-\propto *(\mathrm{~N}-$ $\left.1)+p^{*}(1-p)\right]$ at power $80 \%$ and CI $95 \%$. The 


\section{Health Care Provided by Hospital Staff and its Relation with Quality of Administrative System of Hospital}

total sample size of the study was 440 participants (Kevin \& Sullivan, 2018). Probability simple random sample technique was used to select staff nurses, staff physicians, and administrative employees. The researcher used random ball method to choose the participants from Menoufia university hospital. This technique increases the representativeness of the sample. The sample included four groups:

1. Group1: Simple random sample of 134 staff nurses were selected to constitute the present study sample from Menoufia university hospitals.

2. Group2: Simple random sample of 32 staff Physicians were selected to constitute the present study sample from Menoufia university hospitals.

3. Group3: Simple random sample of 199 administrative employees were selected to constitute the present study sample from Menoufia university hospitals.

4. Group4: convenient sample of 75 patients were selected to constitute the present study sample from Menoufia university hospitals.

- Instruments for data collection: Two instruments were used for collecting data:

Instrument one: Staff perception structured questionnaire sheet was developed by the researcher based on a review of current related literature (Ali, 2001. Said, 2008. Egyptian Ministry of Health, Human Resources Administration, 2013). It was provided to staff nurses, staff physicians and administrative employees to assess their perception regarding the quality of administrative system at Menoufia University hospital. It included two parts:

- Part A: Characteristics of staff: staff job, educational level, age, and years of experience.

- Part B: It Included questions to assess the perception of staff nurses, staff physicians and administrative employees regarding to the quality of administrative system at Menoufia University hospital. The instrument was divided into three categories: quality of administrative system structure, quality of process of administrative system and quality of outcome of administrative system. The administrative system included 89 items, structure contained sixteen items, process contained 63 items (ten for planning, nine for organizing, eight for directing, ten for coordinating, ten for controlling, seven for leading and nine for working relationship) and outcome contained ten items.

Scoring system for Staff perception structured questionnaire:

Each instrument was scored as follows:

\begin{tabular}{|l|l|}
\hline Strongly Disagree & 1 \\
\hline Disagree & 2 \\
\hline No definite opinion & 3 \\
\hline Agree & 4 \\
\hline Strongly Agree & 5 \\
\hline
\end{tabular}

Total scoring system:

\begin{tabular}{|l|c|}
\hline Low & $89-207.6$ \\
\hline Moderate & $207.7-326.3$ \\
\hline High & $326.4-445$ \\
\hline
\end{tabular}

Instrument two: Patients perception structured interview. It was developed to investigate the patients' perception toward quality of health care provided by hospital staff in Menoufia University hospital. The researcher developed it based on review of current related literature (Mohamed, 1998, Williams, 2015). It included two parts as follows:

- Part A: Characteristics of patients. It included unit, sex, age, educational level, job, and marital status.

- Part B: Patients perception of quality of health care: it included questions to assess the perception of the patients toward the quality of health care provided by hospital staff in Menoufia University hospital. It included 52 questions distributed under five categories which were: hospital characteristics, physician's services, nurse's services, supportive services, and administrative employee's services. 
Hospital characteristics included 4 items, physicians included 13 items, nurses included 12 items, supportive services included 16 items, and administrative employees included 7 items.

\section{Scoring system for patients' structured interview:}

Each instrument was scored as follows:

\begin{tabular}{|l|l|}
\hline Strongly Disagree & 1 \\
\hline Disagree & 2 \\
\hline No definite opinion & 3 \\
\hline Agree & 4 \\
\hline Strongly Agree & 5 \\
\hline
\end{tabular}

Total scoring system:

\begin{tabular}{|l|c|}
\hline Low & $52-121.3$ \\
\hline Moderate & $121.4-190.6$ \\
\hline High & $190.7-260$ \\
\hline
\end{tabular}

Data collection procedure:

\section{Ethical considerations:}

1-A formal letter was submitted from the Dean of the Faculty of Nursing, Menoufia University to the director of Menoufia University hospital explaining the purpose and methods of data collection.

2-The written consent was taken from the study subjects and the approval of ethical committee was obtained. The researcher explained to hospital staff and patients the objectives of the study, informed confidentiality and anonymity being assured.

3-Each participant was individually interviewed.

4-Each interview lasted for 20-25 minutes. The researcher started by asking questions about hospital characteristics then, each participant was asked about the services provided to them by nurses, physicians, administrative employees, and support services.

\section{Validity:}

The data collection instruments were developed by researcher after extensive review of past and current, local and international related literature. The instruments were revised for content validity by eleven juries (five experts from Tanta University, one expert from Cairo University, one expert from Ein-Shams University, one expert from Helwan University, and three experts from Menofia University) who were experts in in nursing administration.

\section{Reliability:}

The instruments were tested for reliability by Cronbach's co-efficiency Alpha (0.81) for the MUH staff questionnaire, and (0.78) for the patient questionnaire. Necessary modifications including clarifications, omissions, of some questions and rephrasing of other were done.

\section{Pilot study:}

A pilot study was carried out on $(10 \%)$ of the total sample (10 nurses, 3 physicians and 19 employees) and data was analyzed and compared. Data was collected over a period of three months. It started at November 2017 and ended on January 2018.

\section{Statistical Analysis:}

Data was entered and analyzed by using SPSS version 22. Quantitative data were presented by mean (X) and standard deviation (sd). Student ttest was used for comparison between two means, and ANOVA $(F)$ test was used for comparison between more than two means. Qualitative data were presented in the form of frequency distribution tables, number and percentage. It was analyzed by chi-square $\left(\chi^{2}\right)$ test. However, if an expected value of any cell in the table was less than 5, Fisher Exact test was used( if the table was 4 cells) , or Likelihood Ratio (LR) test (if the table was more than 4 cells). Level of significance was set as $\mathrm{P}$ value $<0.05$ for all significant tests. 


\section{Health Care Provided by Hospital Staff and its Relation with Quality of Administrative System of Hospital}

\section{Results:}

Figure1. highlighted the socio demographic characteristics of staff participants. As showed in this figure, more than half of between 30 to $<50$ years. $53.2 \%$ of them had Bachelor degree and $37 \%$ of them had experience $\geq 15$ years

Table 1. showed distribution of patients participants according to their Sociodemographic characteristics. As inferred in this table, forty percent of patients were from ICU, approximately three quarters of them were females, $58.7 \%$ of them aged less than 30 years, $70.6 \%$ of them had high school, and $32 \%$ of them were housewives. As regards marital status, $64 \%$ of them were married and $36 \%$ were unmarried.

Table 2. highlighted the administrative system total quality in MUH among staff participants. As noticed in this table, the total mean score of quality was $255.9 \pm$ 77.9 , with a range of $109-439$. Nursing staff showed the highest total mean score (271.1 \pm 80.3), followed by Physician staff $(248.5 \pm 70.1)$, and the lowest mean score was among Administrative staff (246.8 士76.2). The difference was significant statistically $(\mathrm{P}=0.01)$. Unfortunately, less than one fifth of staff responses denoted that total quality in MUH administrative system was high (18.6\%), while $31.2 \%$ denoted that total quality in MUH administrative system was low, while the majority (half of them) denoted that it was moderate. There was significant difference between nurses, physicians and administrative staff regarding quality groups of total administrative system scores $(\mathrm{P}=0.04)$.

Table 3. showed the perception of patients towards health care provided by MUH. As presented in this table, the majority of patients denoted moderate quality regarding the following domains: hospital characters (41.3\%), services provided to patients by administrative employee (56\%), services provided to patients by physicians $(57.3 \%)$, services provided to patients by nurses $(60 \%)$, and services provided to patients by studied staff were administrative employee (54.5\%), while nursing staff were $36.7 \%$. Concerning their

age, 55.6\% of them aged

supportive services $(58.7 \%)$. There were statistical significant differences between male and female patients regarding their opinions about quality of services provided by administrative employee $(\mathrm{P}=0.003)$, services provided by nurses $(\mathrm{P}=0.03)$, and total score of health care provided by $\mathrm{MUH}$ $(\mathrm{P}=0.04)$.

Table 4. showed the relationship between the quality of administrative system among staff and health care provided to the patients at Menoufia University hospital. As inferred in this table, $14.7 \%$ of patients perceived that the quality of services provided by MUH was low, more than two thirds of patients perceived that the quality of services provided by MUH was moderate $(66.7 \%)$, and less than one-fifth perception was high $(18.6 \%)$. There was statistical significant differences between patients perception and each administrative employee, and total quality score administrative system of staff $(\mathrm{P}=0.005$, $\mathrm{P}=0.04$ respectively). On the other hand there was no statistical significant difference between patients perception and each of nursing staff and physician staff $(\mathrm{P}=0.48, \mathrm{P}=0.20$ respectively.

Table 5.demonstrated the high significant positive correlation between quality of administrative system from nurses staff $(\mathrm{r}=0.810, \mathrm{P}=0.000), \quad$ quality of administrative system from physician staff $(\mathrm{r}=0.872, \mathrm{P}=0.000)$, and quality of administrative system from administrative employee staff $(\mathrm{r}=0.831, \mathrm{P}=0.000)$, and their correlation with the quality of health care provided to patients in MUH. The higher the quality of administrative system among each of physicians, nurses, and administrative employee, the higher will be the quality of health care to patients in MUH 


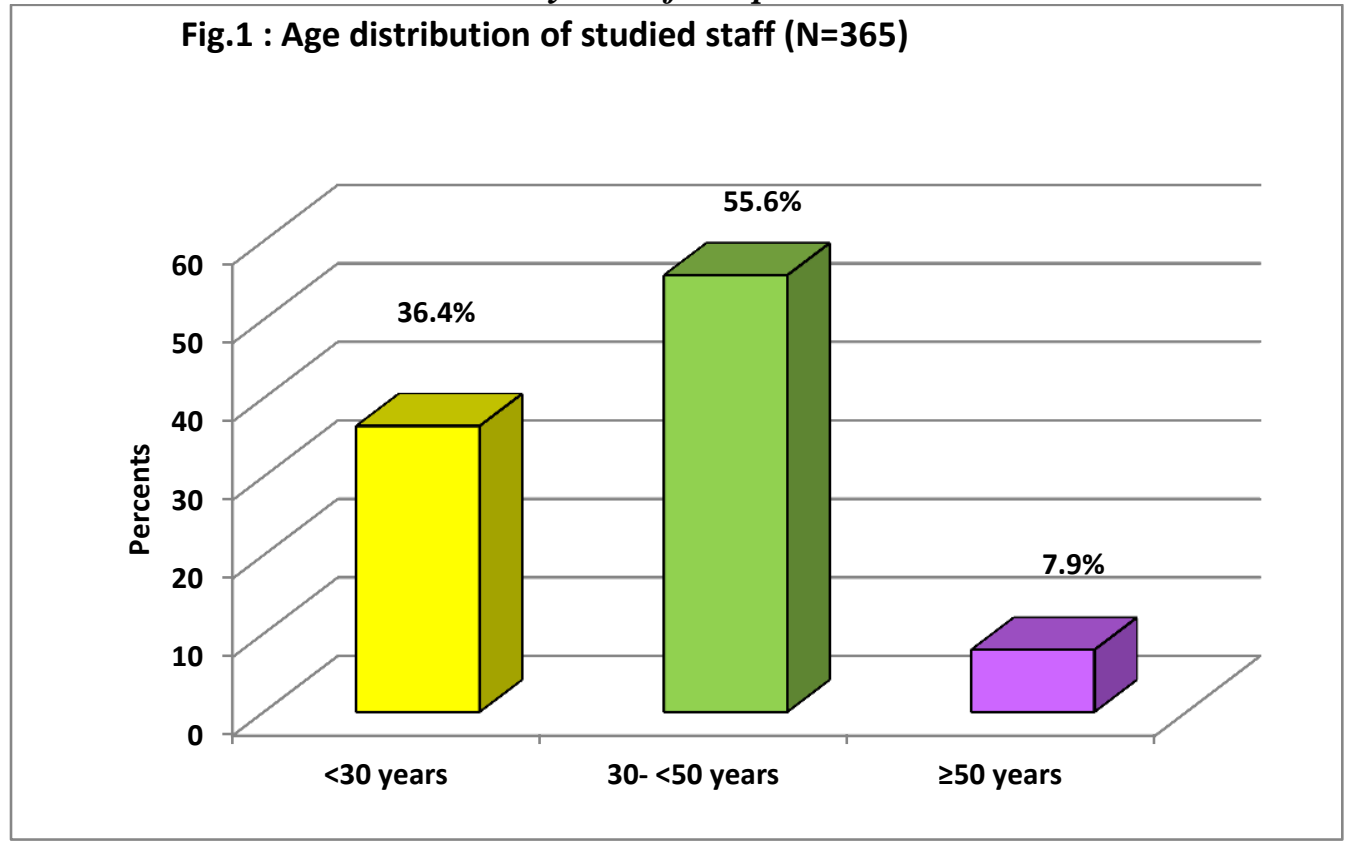

Table 1. Distribution of Participants According to Their Socio-Demographic Characteristics ( $\mathrm{N}=$ 75)

\begin{tabular}{|l|c|c|}
\hline $\begin{array}{l}\text { Socio demographic } \\
\text { characteristics }\end{array}$ & N0. & \% \\
\hline $\begin{array}{l}\text { Participants' unites: } \\
\text { ICUs }\end{array}$ & $\mathbf{3 0}$ & $\mathbf{4 0}$ \\
\hline Obstetric & $\mathbf{1 2}$ & $\mathbf{1 6}$ \\
\hline Emergency & $\mathbf{1 0}$ & $\mathbf{1 3 . 3}$ \\
\hline Medical & $\mathbf{9}$ & $\mathbf{1 2}$ \\
\hline Others* & $\mathbf{1 4}$ & $\mathbf{1 8 . 7}$ \\
\hline Gender & $\mathbf{1 9}$ & $\mathbf{2 5 . 3}$ \\
Male & $\mathbf{5 6}$ & $\mathbf{7 4 . 7}$ \\
\hline Female & 44 & 58.7 \\
\hline Age (Yeaars) & 22 & 29.3 \\
<30 yrs & 9 & 12 \\
30 - 50 yrs & & \\
$\geq$ 50 yrs & 53 & 70.6 \\
\hline Educational Level & 20 & 26.7 \\
High school & 2 & 2.7 \\
Bachelor degree & 24 & 32 \\
Master degree & 17 & 22.7 \\
\hline Job: & 14 & 18.7 \\
Housewives & 20 & 36.6 \\
Students & & 64 \\
Professional & 48 & 100 \\
Others* & 27 & \\
\hline Marital status: & & \\
Married & 75 & \\
Unmarried & & \\
\hline Total & & \\
\hline & & \\
\hline
\end{tabular}

*= Surgical, Pediatric units. \#= Employee, private job, pension.

Table 2. Quality of the Administrative System at Menoufia University Hospitals from the Points of View of Hospital Staff (Structure, Process and Outcome) 
Health Care Provided by Hospital Staff and its Relation with Quality of Administrative System of Hospital

\begin{tabular}{|c|c|c|c|c|c|c|c|c|c|}
\hline \multirow{3}{*}{$\begin{array}{c}\text { Quality of } \\
\text { administrative system }\end{array}$} & \multicolumn{6}{|c|}{ Hospital staff Participants } & \multirow{2}{*}{\multicolumn{2}{|c|}{ Total }} & \multirow{3}{*}{$P$ value } \\
\hline & \multicolumn{2}{|c|}{ Nursing staff } & \multicolumn{2}{|c|}{$\begin{array}{c}\text { Physician } \\
\text { staff }\end{array}$} & \multicolumn{2}{|c|}{$\begin{array}{c}\text { Administrative } \\
\text { employees }\end{array}$} & & & \\
\hline & no. & $\%$ & no. & $\%$ & no. & $\%$ & no. & $\%$ & \\
\hline $\begin{array}{c}\text { Low } \\
(89-207.6)\end{array}$ & 33 & 24.6 & 7 & 21.9 & 74 & 37.2 & 114 & 31.2 & \\
\hline $\begin{array}{c}\text { Moderate } \\
\text { 326.3) }\end{array}$ & 70 & 52.2 & 21 & 65.6 & 92 & 46.2 & 183 & 50.2 & $X^{2}=9.8$ \\
\hline $\begin{array}{c}\text { High } \\
(326.4-445)\end{array}$ & 31 & 23.2 & 4 & 12.5 & 33 & 16.6 & 68 & 18.6 & $\mathrm{P}=0.04 \mathrm{Sig}$. \\
\hline Total & 134 & 100 & 32 & 100 & 199 & 100 & 365 & 100 & \\
\hline $\mathrm{X} \pm \mathrm{SD}$ & \multicolumn{2}{|c|}{$271.1 \pm 80.3$} & \multicolumn{2}{|c|}{$248.5 \pm 70.1$} & \multicolumn{2}{|c|}{$246.8 \pm 76.2$} & \multicolumn{2}{|c|}{$255.9 \pm 77.9$} & \multirow{2}{*}{$\begin{array}{c}F=4.1, \\
P=0.01 \mathrm{Sig} .\end{array}$} \\
\hline Range & \multicolumn{2}{|c|}{$130-437$} & \multicolumn{2}{|c|}{$135-430$} & \multicolumn{2}{|c|}{$109-439$} & \multicolumn{2}{|c|}{$109-439$} & \\
\hline
\end{tabular}

Table 3. Perception of Patients towards Health Care Provided by Hospital Staff (N=75)

\begin{tabular}{|c|c|c|c|c|c|c|c|c|}
\hline \multirow{3}{*}{\multicolumn{2}{|c|}{$\begin{array}{l}\text { Perception of patients towards health care } \\
\text { provided by hospital staff }\end{array}$}} & \multicolumn{4}{|c|}{ Patients participants } & \multirow{2}{*}{\multicolumn{2}{|c|}{ Total }} & \multirow{4}{*}{$P$ value } \\
\hline & & \multicolumn{2}{|c|}{ Male } & \multicolumn{2}{|c|}{ Female } & & & \\
\hline & & no. & $\%$ & no. & $\%$ & no. & $\%$ & \\
\hline \multirow{3}{*}{$\begin{array}{c}\text { Hospital } \\
\text { characters }\end{array}$} & Low (4-9.3) & 5 & 26.4 & 20 & 35.7 & 25 & 33.4 & \\
\hline & Moderate (9.4 - 14.6) & 7 & 36.8 & 24 & 42.9 & 31 & 41.3 & \multirow{2}{*}{$\mathrm{X}^{2}=1.8, \mathrm{P}=0.4 \mathrm{NS}$} \\
\hline & High (14.7 - 20) & 7 & 36.8 & 12 & 21.4 & 19 & 25.3 & \\
\hline \multirow{3}{*}{$\begin{array}{c}\text { Physicians } \\
\text { health services }\end{array}$} & Low (13 -30.3) & 4 & 21.1 & 13 & 23.2 & 17 & 22.7 & \multirow{3}{*}{$\begin{array}{c}\mathrm{X}^{2}=0.63, \mathrm{P}=0.7 \\
\mathrm{NS}\end{array}$} \\
\hline & Moderate (30.4 -47.6) & 10 & 52.6 & 33 & 58.9 & 43 & 57.3 & \\
\hline & High (47.7- 65 & 5 & 26.3 & 10 & 17.9 & 15 & 20 & \\
\hline \multirow{3}{*}{$\begin{array}{c}\text { Nurses health } \\
\text { services }\end{array}$} & Low (12-28) & 2 & 10.5 & 6 & 10.7 & 8 & 10.7 & \multirow{3}{*}{$\begin{array}{c}\mathrm{X}^{2}=7.9, \mathrm{P}=0.03 \\
\text { Sig. }\end{array}$} \\
\hline & Moderate (28.1-44.1) & 7 & 36.8 & 38 & 67.9 & 45 & 60 & \\
\hline & High (44.2- 60) & 10 & 52.7 & 12 & 21.4 & 22 & 29.3 & \\
\hline \multirow{3}{*}{$\begin{array}{c}\text { Supportive } \\
\text { health services }\end{array}$} & Low (16 - 37.3) & 6 & 31.5 & 13 & 23.2 & 19 & 25.3 & \multirow{3}{*}{$\begin{array}{c}\mathrm{X}^{2}=1.3, \mathrm{P}=0.50 \\
\mathrm{NS}\end{array}$} \\
\hline & Moderate (37.4-58.6) & 9 & 47.4 & 35 & 62.5 & 44 & 58.7 & \\
\hline & High (58.7- 80) & 4 & 21.1 & 8 & 14.3 & 12 & 16 & \\
\hline \multirow{3}{*}{$\begin{array}{l}\text { Administrative } \\
\text { employee health } \\
\text { services }\end{array}$} & Low (7- 16.3) & 3 & 15.8 & 12 & 21.4 & 15 & 20 & \multirow{3}{*}{$\begin{array}{l}\mathrm{X}^{2}=11.6, \mathrm{P}=0.003 \\
\text { Sig. }\end{array}$} \\
\hline & Moderate (16.4- 25.6) & 6 & 31.6 & 36 & 64.3 & 42 & 56 & \\
\hline & High (25.7- 35) & 10 & 52.6 & 8 & 14.3 & 18 & 24 & \\
\hline \multirow{3}{*}{$\begin{array}{c}\text { Total Score } \\
\text { Range= } \\
52-260\end{array}$} & Low $(52-121.3)$ & 2 & 10.5 & 9 & 16.1 & 11 & 14.7 & \multirow{3}{*}{$\begin{array}{c}\mathrm{X}^{2}=7.5, \mathrm{P}=0.04 \\
\text { Sig. }\end{array}$} \\
\hline & Moderate (121.4-190.6) & 10 & 52.7 & 40 & 71.4 & 50 & 66.7 & \\
\hline & High (190.7- 260) & 7 & 36.8 & 7 & 12.5 & 14 & 18.6 & \\
\hline & Total & 19 & 100 & 56 & 100 & 75 & 100 & \\
\hline
\end{tabular}

Table 4. Perception of Nurses, Physicians and Administrative Employees about the Quality of Administrative Systems 
Health Care Provided by Hospital Staff and its Relation with Quality of Administrative System of Hospital

\begin{tabular}{|c|c|c|c|c|c|c|c|c|c|c|}
\hline \multirow{4}{*}{$\begin{array}{c}\begin{array}{c}\text { Quality of } \\
\text { administrative } \\
\text { system among } \\
\text { studied staff }\end{array} \\
\text { Low }\end{array}$} & \multicolumn{6}{|c|}{ Staff participants } & \multirow{2}{*}{\multicolumn{2}{|c|}{ Total }} & \multirow{3}{*}{\multicolumn{2}{|c|}{$\begin{array}{c}\text { Patients } \\
\text { perception } \\
\text { about MUH } \\
\text { services }\end{array}$}} \\
\hline & \multicolumn{2}{|c|}{$\begin{array}{l}\text { Nursing } \\
\text { Staff }\end{array}$} & \multicolumn{2}{|c|}{$\begin{array}{c}\text { Physician } \\
\text { staff }\end{array}$} & \multicolumn{2}{|c|}{$\begin{array}{c}\text { Administrative } \\
\text { employees }\end{array}$} & & & & \\
\hline & \multirow{2}{*}{$\begin{array}{c}\text { No. } \\
33 \\
\end{array}$} & \multirow{2}{*}{$\begin{array}{c}\% \\
24.6 \\
\end{array}$} & \multirow{2}{*}{$\frac{\text { No. }}{7}$} & \multirow{2}{*}{$\begin{array}{c}\% \\
21.9\end{array}$} & \multirow{2}{*}{$\frac{\text { N0. }}{74}$} & \multirow{2}{*}{$\begin{array}{c}\% \\
37.2 \\
\end{array}$} & \multirow{2}{*}{$\begin{array}{l}\text { No } \\
114 \\
\end{array}$} & \multirow{2}{*}{$\begin{array}{c}\% \\
31.2 \\
\end{array}$} & & \\
\hline & & & & & & & & & 11 & 14.7 \\
\hline Moderate & 70 & 52.2 & 21 & 65.6 & 92 & 46.2 & 183 & 50.2 & 50 & 66.7 \\
\hline High & 31 & 23.2 & 4 & 12.5 & 33 & 16.6 & 68 & 18.6 & 14 & 18.6 \\
\hline Total & 134 & 100 & 32 & 100 & 199 & 100 & 365 & 100 & 75 & 100 \\
\hline$* \chi^{2}$ & \multicolumn{2}{|c|}{$\chi^{2}=0.48$} & \multicolumn{2}{|c|}{$\chi^{2}=1.6$} & \multicolumn{2}{|c|}{$\chi^{2}=7.6$} & \multicolumn{2}{|c|}{$\chi^{2}=4.1$} & & \\
\hline$* \mathbf{P}$ value & \multicolumn{2}{|c|}{$\mathrm{P}=0.48 \mathrm{~ns}$} & \multicolumn{2}{|c|}{$\mathrm{P}=0.20 \mathrm{~ns}$} & \multicolumn{2}{|c|}{$\mathrm{P}=0.005 *$} & \multicolumn{2}{|c|}{$\mathrm{P}=0.04 *$} & & \\
\hline Mean \pm SD & \multicolumn{2}{|c|}{$271.1 \pm 80.3$} & \multicolumn{2}{|c|}{$248.5 \pm 70.1$} & \multicolumn{2}{|c|}{$246.8 \pm 76.2$} & \multicolumn{2}{|c|}{$\begin{array}{l}\mathrm{F} \text { test }=32.7, \\
\mathrm{P}=0.000 * *\end{array}$} & \multicolumn{2}{|c|}{$157.8 \pm 35.4$} \\
\hline
\end{tabular}

F test = Comparison between each of nursing, physician, administrative staff, and total staff 'mean \pm SD of total score of quality of administrative system with mean \pm SD of total score of patients perception about Menoufia University Hospital services.

$\mathrm{ns}=\mathrm{P}>.05 \quad *=\mathrm{P} \leq .05 \quad * *=\mathrm{P} \leq .01$

Table 5: Correlation between Quality of Administrative System from the Points of View of Nurses, Physicians and Administrative Employees in Menoufia University Hospital.

\begin{tabular}{|l|c|c|c|c|c|}
\hline \multicolumn{1}{|l|}{} & $\begin{array}{c}\text { Quality of } \\
\text { administrative } \\
\text { system from } \\
\text { physicians staff }\end{array}$ & $\begin{array}{c}\text { Quality of } \\
\text { administrative } \\
\text { system from } \\
\text { nurses staff }\end{array}$ & $\begin{array}{c}\text { Quality of } \\
\text { administrative } \\
\text { system from } \\
\text { administrative } \\
\text { employee staff }\end{array}$ & $\begin{array}{c}\text { Quality of } \\
\text { health care to } \\
\text { patients }\end{array}$ \\
\hline $\begin{array}{l}\text { Quality of administrative } \\
\text { system from physicians staff }\end{array}$ & $\begin{array}{c}\text { Pearson } \\
\text { correlation } \\
\mathrm{P}\end{array}$ & 1 & & 1 & \\
\hline $\begin{array}{l}\text { Quality of administrative } \\
\text { system from nurses staff }\end{array}$ & $\begin{array}{c}\text { Pearson } \\
\text { correlation } \\
\mathrm{P}\end{array}$ & $0.000 * *$ & 0.595 & 1 \\
\hline $\begin{array}{l}\text { Quality of administrative } \\
\text { system from administrative } \\
\text { employee staff }\end{array}$ & $\begin{array}{c}\text { Pearson } \\
\text { correlation } \\
\mathrm{P}\end{array}$ & 0.729 & 0.000 & 0.810 & 0.831 \\
\hline $\begin{array}{l}\text { Quality of health care to } \\
\text { patients }\end{array}$ & $\begin{array}{c}\text { Pearson } \\
\text { correlation } \\
\mathrm{P}\end{array}$ & 0.872 & 0.000 & 0.000 & 1 \\
\hline
\end{tabular}

\section{Discussion:}

Recently, much pressure has been exerted on health care institutions to improve the efficiency and competitive advantages of their institutions in relation to cost effectiveness and quality of care. The reasons behind this movement are increasing in complexity of health care organizations, increasing competition in the health care market, ongoing process of (sub-) specialization of health care providers, and increasing awareness on patient safety. These reasons lead to the adoption of quality management system in hospitals (Siddiqui, 2016).

Regarding quality of administrative system, the current study revealed that, the total mean score of quality administrative system was moderate. Nursing staff showed the highest total mean score, followed by Physician staff, and the lowest mean score was 


\section{Health Care Provided by Hospital Staff and its Relation with Quality of Administrative System of Hospital}

among Administrative staff. There was significant difference between nurses, physicians and administrative staff regarding the total quality of administrative system scores. This was contradicted with Aiken et. al, (2012). Who studied "hospital staffing, organization and quality of care". They found that high percentages of nurses rated poor total quality in all studied hospitals. Also, these findings were inconsistent with Ibrahim (2016). Who studied "organizational features of work environment and nurses' quality of work life". They found that unit facilities were inadequate to provide care of high quality and the collaborative relationships with physicians are lacking. These could be attributed to lack of delegation of managerial personnel on its three categories, and they were occupied with day-to-day activities due to shortage of staff, lack of managerial supervision, lack of participation in preparing schedules, lack of autonomy, motivation and decision involvement.

Regarding the quality of health care services provided to patients, the current study revealed that majority of patients showed moderate quality of health services provided to them by nurses, physicians, administrative employees, and supportive services. There were statistical significant difference between male and female patients regarding their opinions about quality of services provided by administrative employee, services provided by nurses, and total score of health care provided by hospital staff. This was consistent with Adam \& Elsawi (2011). Who studied "patient satisfaction with health care". They found that the level of patient satisfaction with hospital services was moderate level in the study setting. These could be attributed to patients rooms are not comfortable, physical facilities are insufficient, cleaning services in hospital is moderate, shortage of staff, and work overload. Nurses showed the highest percentage than other groups regarding the services provided to patients because they pay remarkable care and concerns about patients' health, respond quickly to their calls, spending more time spent with them, and give patients adequate and effective explanation about their condition and treatment. On the other hand, this was contradicted with Aly (2011). Who studied "designed a system for quality improvement for the administrative structure of the nursing service department at Kasr El-Einy center of radiation oncology and nuclear medicine". She found that patients were highly dissatisfied with hospital services. Also, this finding was inconsistent with Gharib (2013). Who studied "the job satisfaction of nursing staff versus patient satisfaction with the quality of nursing services at Cairo university hospitals". They found that patients had low satisfaction regarding the health services provided to them. These could be attributed to inadequate supply of essential drugs, patients complain from long waiting time, lack of drugs, inappropriate behaviors of health worker, weak infrastructure and nurses not responding to their calls.

Regarding the relationship between the quality of administrative system denoted by staff and health care provided to the patients at Menoufia University hospital, the current study revealed that although low percent of patients perceived that the quality of services provided by hospital staff was low, more than two thirds of patients perceived that the quality of services provided was moderate. There was statistical significant difference between patients' perception and each of administrative employee, and total quality score administrative system of staff. This was consistent with Hussein (2014). Who studied "the relationship 


\section{Health Care Provided by Hospital Staff and its Relation with Quality of Administrative System of Hospital}

between nurses and physicians' perceptions of organizational health and quality of patient care". They found that there was a significant positive correlation between participants' perception of determinants of the organizational hospital health and the predictors of quality patient care. Also, this finding was similar to Gharib (2013). Who studied "the job satisfaction of nursing staff versus patient satisfaction with the quality of nursing services at Cairo university hospitals". They found that patients' satisfaction is highly correlated with nursing satisfaction. Dissatisfied nurses give poor quality of nursing care or less efficient care. These could be attributed to nurses, physicians, and administrative staff is oriented, and deal with day-to-day problems and determine whether services presented to patients were low or high quality, so they agreed with patients in their opinions that quality of services was moderate.

\section{Conclusions:}

Approximately one quarter of nurses perceived that quality of administrative systems was either low or high. About two thirds of physicians perceived that quality of administrative systems was moderate. Whereas, the majority of administrative employees perceived that quality of administrative systems was either low or moderate.

\section{Recommendations:}

Routine data screening for benchmarking should be systematically conducted to maintain high quality of the administrative system of the hospital. Nursing staff must be continuously motivated to provide high quality nursing care by giving them incentives, fair treatment, flexible scheduling, and autonomy. Activating the role of hospital educational unit to encourage staff to participate in the programs according to their needs. Designing in-service educational programs based on management educational needs of novice nursing and medical staff to improve moderate quality of administrative tasks. Further researches are needed in Egypt to assess the barriers that affect the quality of administrative tasks among nurse managers.

\section{References:}

Adam, S.M. and Elsawi, K.A. (2011). Patient satisfaction with health care: the case of five multisectional hospitals. Journal of Medicine; 22(2): 16-27.

Aiken, L. H., Clarke, S. \& Sloane, D.M. (2002). Hospital staffing, organization, and quality of care: cross sectional findings. International Journal for Quality in Health Care; 14(1): 5-14.

Ali, N. (2001). Evaluation of the administrative system of the elderly houses in El Gharbyia governorate. Master dissertation. Faculty of Economic, Menoufia University. 210 - 19.

Aly, S.H. (2011). Designing a system for quality improvement for the administrative structure of the nursing service department at Kasr El-Einy center of radiation oncology and nuclear medicine Doctoral dissertation. Faculty of Nursing, Cairo University. 130 132.

Barr, J. (2012). Health administration: hospital administrators. Retrieved from:

http://en.wikipedia.org/wikihealth administration

Dibiaggio, J.A. \& White, R.P. (2015). Administrative structure of an accredited hospital.US National Library of Medicine, National Institute of Health; 19(4): 579-86. 


\section{Health Care Provided by Hospital Staff and its Relation with Quality of Administrative System of Hospital}

Egyptian Ministry of Health, Human Resources Administration. (2013). Standards of Evaluating and Monitoring Hospitals Performance: $42-48$.

Gharib, S.A. (2013). Job satisfaction of nursing staff, versus patients' satisfaction with the quality of nursing services at Cairo University hospitals. Master dissertation. Cairo University. 8090.

Hughes, R.G., and Steinwachs, D.M. (2008). Health services: scope, and significance. Retrieved from: www.ncbi.nlm.nih.gov/Book/NB K2660.http://oureverydaylife.com /skills-needed-administrativejob1148. htm

Hussein, H.M. (2014). Relationship between nurses and physicians' perceptions of organizational health and quality of patient care. Eastern Mediterranean Health Journal; 20(10): 634-36.

Ibrahim, E.E. (2016). Organizational features of work environment and nurses' quality of work life. Master dissertation. Faculty of Nursing, Menoufia University. 101-104.

Kelly, P. (2012). Managing Quality and Risk. Leading and Managing in Nursing. 3rd ed. South-Western Cengage Learning Press. USA. 31-40.

Kevin, T. and Sullivan, A. (2018). Open Epi: sample size for Xsectional, Cohort and Clinical Trials. Retrieved from http://www.openepi.com/Sample Size/SSCohort.htm.

Marquis, B. and Huston, C. (2011). Leadership Roles and Management in Nursing: Theory and application. Lippincott co. New York. 469-76.
Mohamed, R.A. (1998). The effect of using total quality management on the efficiency of the general authority for health insurance hospitals. Master dissertation. Faculty of Commerce, Tanta University.

Mosadeghrad A.M. (2014). Factors influencing health care Service quality. Journal of Health Policy and Management; 3(2): 77-89.

Petri, J. and Kazemi A. (2015). Structure and process quality as predictors of satisfaction with elderly care in the community. Health and Social Care Journal; 24(6): 699-07.

Said, A.M. (2008). Organizational structure features influence on occupational stress for intensive care nurses and strategies for dealing with stress. Doctoral dissertation. Faculty of Nursing, Mansoura University). 93-110.

Salah, S A. (2016). Quality of nursing care barriers in critical care units at Tanta university hospitals. Master dissertation. Faculty of Nursing, Tanta University. 6-10.

Siddiqui, M.I. (2016). Hospital Administration. 8th ed. Time Publishers company. 235-46.

Williams, C. (2013). Principles of Management. Southwestern Learning Press. USA. 4-27.

Williams D. (2015). Patient satisfaction survey. Factors influencing patient satisfaction in Hospitals. Retrieved from: https://www.surveymonkey.com/r IZNCZ3RC

Wolper, L.F. (2011). Health Care Administration: Managing Organized Delivery Systems. 5th ed. Jones and Barttlet Press. London. 653-74. 